\title{
THE IMPACT OF CHRISTIANITY ON THE DEVELOPMENT OF PERSONAL NAMES IN MEDIAEVAL SCANDINAVIa
}

\author{
Camelia Ștefan \\ University of Bucharest, Romania
}

\begin{abstract}
The conversion of the Nordic countries to Christianity, largely completed in the $13^{\text {th }}$ century, exerted a profound influence not only on Scandinavian society and its spiritual life, but also on the linguistic practices of name-giving. Hence, the purpose of this article is twofold: (i) to outline the process of introduction of the new religion in the Scandinavian countries and the conflict with the heathen cultic elements, and (ii) to account for the changes in the Scandinavian onomasticon of personal names after the importation of Christian foreign names. The paper draws on early religious and literary sources and includes an etymological analysis of the aforementioned personal names as a result of language contact with Latin and Greek.
\end{abstract}

Keywords: Christianity, language contact, Latin, Scandinavian onomastics.

\section{Introduction}

Onomastics has been the focus of various disciplines, including anthropology, history, philosophy and many more. It is essential to linguistics, shedding new light on the processes of human communication. Starting with Shakespeare's famous line in Romeo and Juliet, "What's in a name?", the answer to this is that a name can reveal everything one wants to know, from the practical function of distinguishing individuals to the origin, history and development of a particular society.

The present paper is an anthroponymic study of given names in Northern Europe throughout the mediaeval period. Its aim is twofold: firstly to describe the historical context at the time when Scandinavia was Christianized, and secondly, to account for the linguistic changes in the inventory of personal names and the conflict with the cultic elements. The study draws primarily on sources available for this period, namely inscriptions on rune stones, artifacts and written documents from a later period.

The paper is organized as follows. Section 2 outlines the socio-historical background of the events that led to the Christianization of the Nordic countries. Section 3 outlines briefly the impact of the new religion in the lexical domain. Section 4 describes the development of personal names in Scandinavia, from the Viking period (ca. 800-1050 AD) to the Late Middle Ages ( $14^{\text {th }}$ century). First, the Germanic system of name-giving is described, followed by the changes in the naming practices after the conversion to Christianity and the introduction of the Latin alphabet. The conclusions are summarized in section 5 . 


\section{The Christianization of the North}

From the beginning of the $9^{\text {th }}$ century, the Vikings ${ }^{1}$ of Scandinavia, in their raids and voyages for trade, came into intensive contact with the Continent. Their centuriesold religion based on gods and pagan mythology was faced with a new faith: southern and western Christianity. As economic integration increased, the Christian intolerance of paganism forced the Vikings to renounce their beliefs and undergo exorcism or baptism in order to establish trade or settlements in Christian territories (Schottmann 2002).

The conversion of the North to Christianity was assigned to the archdiocese of Hamburg, founded in 831, and Bremen, in 845 (Schottmann 2002). Nordic missions followed trading routes and arrived in the Viking towns of Hedeby on Jutland, Birka in Sweden, and possibly reached southern Norway. For instance, the French missionary Ansgar made unsuccessful attempts at introducing Christianity and setting up the first church in Birka in 829. As the anti-Christian sentiment was strong among the Svear², it was only in the $11^{\text {th }}$ century that Christianity began to take root, as evidenced by the runic inscriptions and artifacts embellished with Christian symbols (Kent 2008).

Olof Eriksson Skötkonung (980-1022) was the first Swedish king who had converted to Christianity and introduced coins displaying Latin words and Christian symbols, inspired by English pennies. The Anglo-Saxon influence was consolidated by English clerics who arrived in Sweden to propagate Christianity and the new way of living. The arrival of Adam of Bremen proved to be crucial for the dissemination of Christianity which came to be adopted not only by the higher social classes, but also by the general population. As the distribution of Christian names shows, changes in the practice of name-giving spread from second baptismal names for the elites, followed by names for daughters pertaining to noble families before becoming common for the general population in the $12^{\text {th }}$ century (Reichert 2002).

Olof Eriksson's successors continued the conversion to the new faith and an episcopal seat was established at Sigtuna, near the ancient Temple of Uppsala. It was moved in 1164 to Uppsala itself, thus ending or subsuming the ancient pagan practices. New laws were promulgated, such as Upplandslagen 'the Law of Uppland' (1296-1350) which forbade old pagan customs, like the worship of gods, groves of sacred trees and stones (Kent 2008).

In Denmark, King Harald Bluetooth (935-985) professed Christianity and contributed to the expansion of the new religion under strong Anglo-Saxon influence as the political center was transferred to the Danelaw. The heathen personal and place names still surviving today suggest a more tolerable Christian mission. According to Kousgård Sørensen (1990: 398), Christianity was not imposed upon the general Danish population such that the old religion had to be banished, but rather superseded peacefully and gradually.

\footnotetext{
The term Viking itself denotes 'one who came from the fjords', < ON vik 'bay, inlet'.

North Germanic tribe who settled in the central part of Sweden. Cf. Svea-rike 'realm of the Swedes' > Sverige 'Sweden'.
} 
In Norway, the introduction of Christianity by King Hákon Haraldsson had met the opposition of the pagan farmers in the $10^{\text {th }}$ century. Anglo-Saxon missionaries sent from England and Germany had met resistance as well, but paved the way for King Olav Tryggvason (960-1000) who built the first church, and King Olaf Haraldsson (995-1030) who is credited with the final conversion of Norway to the new religion (Larsen 1948).

\section{Language change and the new religion}

The earliest European contacts in the North brought about the Latin script, firstly on coinages imitating English models and later handwritten Latin with the Christian missions. The introduction of the Latin alphabet gradually replaced the old runic system of writing known as fupark ${ }^{3}$. In the history of the Swedish language, this borderline marks the distinction between the so-called runsvenska 'Runic Swedish' and klassisk fornsvenska 'Classic Old Swedish.' The oldest book of laws, the Westrogothic Law, was written in Latin script in 1225, whereas the New Testament was first printed and translated in Swedish in 1526 (Bergman 1980).

Christianity had a powerful impact on Old Nordic, leading to lexical changes in the word stock and phraseology. As noted by Astås (2002: 1045), Christianization increased linguistic homogeneity in the Nordic countries, as well as linguistic differentiation $^{4}$. In the West Nordic dialects, represented by Old Icelandic and Old Norwegian, the new terminology was influenced more by the indigenous vocabulary than the eastern dialects, such as Old Danish and Old Swedish which extensively borrowed new religious words from German-speaking areas. Compare the examples given in (1):

(1) a. WN kross 'cross' and OS kors < Lat. crux 'cross'

b. WN skirn 'cleansing' and OS dop 'dip, baptism'

c. WN prenning < prennr 'triple's and OS träfaldoghet 'Holy Trinity'

The rise of Christianity also meant that there was a need for new words denoting new concepts. To illustrate this, Old Swedish adopted terms of Latin or Greek origin, as shown in (2), based on a selection from Bergman (1980: 60):

(2) OS alteri < Lat. altare 'altar'; OS biskuper < Gr. episkopos 'bishop'; OS bref < Lat. breve skriptum 'brief writing'; OS fonter < Lat. fons, fontis 'fountain'; OS ferme < Lat. firmare 'to sign'; OS kalker < Lat. calix 'cup'; OS kape < Lat. capa 'cape'; OS kirkiae < Gr. kyriakon 'chruch'; OS klocke < Lat. clocca 'clock'; OS kloster < Lat. claustrum 'monastery'; OS klerker < Lat. clericus 'clerk'; OS kristin, kristna < Lat. christianus 'christian'; OS krusse $<$ Lat. crucem 'cross'; OS freeedagher ${ }^{6}<$ Lat. dies Veneris 'Friday'; OS messe < Lat. missa

\footnotetext{
3 The name is derived from the first six characters: $f, u, p, a, r$, and $k$.

4 The linguistic differentiation between Old Norse dialects is assumed to have emerged around $1150 \mathrm{AD}$ in a West Norse group and an East Norse group (Haugen 1982).

5 Cf. AS prinis 'Holy Trinity'.

6 Loan translation.
} 
'mass'; OS offer < Lat. offerre 'offer'; OS ola, olia, oling < Lat. oleum 'oil'; OS paskar < Lat. pascha 'Easter'; OS pavi < Lat. papa 'pope', primsignce < Lat. primum signum 'first signing'; OS prester < Lat. presbyter 'presbyter'; OS stol < Lat. stola 'stool'.

The status, function and domains of Latin expanded during the Middle Ages. It was not only new words and a new alphabet that was imported, but also the whole Roman Catholic model of feudalism, secular and ecclesiastical systems, monasteries and formal education. Thus, Latin became the language of Christianity, administrative matters and higher education.

\section{The development of personal names in mediaeval Scandinavia}

Rune stone inscriptions in the so-called "younger futhark" and bracteates found scattered across the Scandinavian countries are the sole linguistic sources of what happened in the North before Christianization. Written documents covering the period 800 until the branching of Old Norse into the old national languages in the $13^{\text {th }}$ century are only sporadic. Peterson (2002: 745) estimates that Sweden has about 3,000 runic inscriptions, Denmark about 320, Norway about 125, and the Faroes only two ${ }^{7}$. Although these contain about 7,000 instances of personal names, the number of single name lemmas can be estimated at approximately 1,300 (The Scandinavian Runic-text Data Base). The following survey on the typology of personal names is mainly based on East Nordic material.

\subsection{The Germanic heritage}

Practices of name-giving before Christian times reflect pagan religious elements. The Germanic languages have three ways of forming personal nomenclature, briefly outlined below (Wessén 1927, Peterson 2002):

(i) Dithematic names: compound names taking two elements which could be combined rather freely ${ }^{8}$

(3) Arn-, Borg-, Ern-, Fast-, Folk-, Geir-, Guð-, Heðin-, Holm-, Ingi-, Ígul-, Jofur-, Ketil-, Ragn-, Sig-, Stein-, Styr-, ping-, por-, Vig-, and the second elements -bjorn, -djarfr, -fastr, -geirr, -njótr, -reifr, -steinn (male names), and -elfr, -frídir, -laug, -vé (female names)

Among the dithematic names, theophoric personal names, i.e. names containing as a first element a word for 'heathen god' or the name of a heathen god, were very frequent during this period. Kousgård Sørensen (1990) emphasizes that nobody would

\footnotetext{
7 Iceland and Greenland have no Viking Age runic inscriptions. Representative sources of personal names are the Landnámabók 'Book of Settlements' and the Íslendinga sögur 'Sagas of the Icelanders'.

8 Inherited from Indo-European (see Peterson 1988).
} 
be called by the name of a heathen god, but rather the name occurred as one element in the compound:

(4) Ansu-, Frey-, pór ${ }^{9}-$, Týr-, Ullr-

(ii) Monothematic: original appellatives using a noun or an adjective:

(5) Bera 'bear', Fākar 'horse', Hrabnar 'raven', Mūha 'heap, mass', Winnar 'one who wins', Braidō 'broad', Hrōrar 'agile', Lamō 'crippled', Leubar 'dear', Swarta 'black', Wakrar 'awake, fresh'

(iii) Derivational names: derived from a noun, adjective or verb:

(6) Assurr/Qssurr, Ás/Æsbjorn, Ásgotr, Bródir, Sveinn, Tobbi, Tófi, Tóki, Tóli, Tómi, Tosti, porgísl/-gils (male names) and Ása, Guðfríðr, Gunnhildr, Tófa, Tóla, Tonna, porgunnr, porvé (female names)

Brylla (2016) defines bynames as secondary formations based on existing words by which a person's main name is followed, an appositional element that could distinguish between persons bearing the same given name. Such an apposition could be a patronymic $(7 \mathrm{a})^{10}$, an adjective $(7 \mathrm{~b})$ or a noun $(7 \mathrm{c})$ :

(7) a. HapuwulfR HeruwulfiR

b. Fastulfr Mjúki 'the soft, limp, gentle one', Tómi Spár 'able to tell fortunes', Rúnulfr hinn Rádspaki 'the wise one who gives good advice'

c. Hnakki 'neck', Hond 'hand', Knapr 'moustache', Lippi 'lip', Nef'nose'

Regarding the systems of name-giving, it is considered that variation was used in the majority of the Indo-European languages (Peterson 1988). Sound changes, in particular the Germanic stress shift, which led to its placement on the first syllable, made alliteration a distinctive trait for Germanic nomenclature. The oldest example of variation within a family is carved on the Blekinge rune stones found in Sweden (Birkmann 1995):

(8) HeruwulfR, HapuwulfR, HariwulfR

Known examples of alliteration can found in the line of kings in the skaldic poem

9 Sørensen (1990) claims that the many names related to the god Tor are unlikely to have been associated with the god in the minds of the people living in the Viking Age. Other names such as the ones in Gud-could be associated with Christian concepts.

10 Patronymics formed from the father's name + son/daughter in the genitive occur about 40 times in runic inscriptions (see Sørensen 1984 for examples). Matronymics occur three times at most (Peterson 2002). 
Ynglingatal and the vowel alliteration in the names of the Swedish kings Emund, Erik (Segersäll) Olof (Skötkonung), Anund and Emund (brothers), thus reflecting an aristocratic custom (Sundqvist and Hultgård 2004).

Another ancient practice was child-naming after another person, a relative or famous ruler. As stated by Peterson (2002), the custom of naming a child after a living relative became more common after Christianization. Some instances found on rune stones are:

(9) a. Bjarnhofði son of Bjarnhofði, Tóki son of Tóki

b. Knútr after Canute the Great, Magnus after King Magnus the Good

It is worth mentioning that the modern use of family names for the common people emerged in Sweden in the $17^{\text {th }}$ century. During the Middle Ages, family names were derived from places of residence and appeared occasionally among burghers and the nobility of German origin (Gillingstam 1971).

In addition to a few isolated cases in Sweden ${ }^{11}$ and in the Danish royal family, the Viking Age runic inscriptions do not evince any personal names of Christian origin even though many inscriptions exhibit Christian symbols such as crosses or prayer formulas (Melefors 2002).

\subsection{Christian names}

Towards the end of the Viking Age, various sources attest the development of names pertaining to the new religion. These early sources include chronicles, charters, confraternity books and memorial lists which reflect the personal nomenclature of the period. However, the texts were written mainly in Latin and, consequently, some names have forms and inflectional endings adapted to Latin patterns.

The system of name-giving consisting of two elements forming a compound was preserved, despite the introduction of the new religion. The existence of heathen as well as Christian names suggests a tolerant attitude towards pagan reminiscences and a peaceful coexistence of the two despite the gradual increase in saints' names. As discussed above, the elements could be represented by words for battle, glory, fame and heathen gods (Melefors 2002):

\section{(10) Gun-, Gunvald, Gup, Guplek, Sigh-, Sigsten, por, porbiorn}

However, the inventory of personal names was significantly expanded after the importation of the foreign names. A popular custom was the naming of children after saints and Biblical persons, so that the old cultic elements began to drop out of

11 The Biblical name Johannes is attested in 13 instances as the Old Nordic adaptations Johan and Jon, together with Nikulas (twice), Klement, Martin, Kristin (female) and Vinaman (after a local martyr) (Eldblad 1994). 
favor and became obsolete ${ }^{12}$. The names were first borne by clerics and later by the nobility, before spreading rapidly to the common people. Among the popular saints' names imported with Christianity were names of Latin, Greek and Hebrew origin, adapted to various Nordic forms. Some examples are discussed below (Melefors 2002: 967):

(i) Iohannes became increasingly common after Christianization in memory of the Jewish prophet John the Baptist, and was derived from the Hebrew male name Yôhānān 'Yahweh is gracious'. The variants Johan and Jon appear in 13 instances on Swedish runic stones. The bishop Ión Qgmundar son is assumed to be the first bearer of this name. The Old Norse collection of sagas Heimskringla attests the variant Ión in Norway as well. The shorter variants Ion, Iohan and Jon were introduced very early in Denmark because stress was shifted to the first syllable. The later forms Iønis and Jøns, as well as Hannus and Hans were introduced in Denmark and Sweden via Low German.

(ii) Nicolaus, the name of the Greek Saint Nicholas is derived from niké 'victory' and laos 'people' and was introduced relatively early in Scandinavia, presumably in the $11^{\text {th }}$ century. It appears in two runic inscriptions in Sweden, while in Denmark, King Niels (1104-1134) is the earliest bearer of the name. With the exception of the form Klaus adopted from German-speaking areas, the variants Nicklas, Nikils, Nighels, Niels, Nils and Nisse became very frequent within Scandinavia.

(iii) Petrus, the name of the apostle Saint Peter, is derived from the Latin petra 'stone' and was recorded in Denmark in 1085 in the name of the king's equerry, and in Sweden in about 1100. The Landnámabók in Iceland mentions a certain Pétrus frá Ósi as early as about 1000, but it was not until the $13^{\text {th }}$ century that the name became common in Norway and Iceland. Other frequent variants in Scandinavia were Pedher, Pelle, Per, Peter and Petter.

(iv) Jacobus, the name of the Hebrew patriarch and the patron of pilgrims, is derived from Hebrew Ya'aqobh 'one that takes by the heel'. It appeared in Scandinavia rather late, first as the name of Danish and Swedish clergymen listed in the Lund cartulary at the end of the $12^{\text {th }}$ century. According to Adam of Bremen and Heimskringla, the Swedish king Anund Jacob (1022-1050) adopted the name upon baptism. In the Late Middle Ages, there were about 8,000 people in Denmark registered with the name $J a c o b$ and its many variants, such as the short Jeep, Jceppe and $I b$ which developed later. In Iceland, an Einarr Iacob son is recorded in the $12^{\text {th }}$ century with no information about his father, whereas in Norway one of the first attestations of the name is that of a parish priest in 1366.

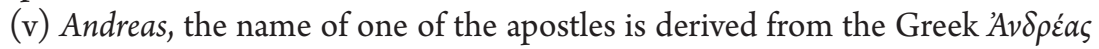
'man'. In Denmark it appeared rather early as the name of various Danish clerics. In Norway it is chronicled through the priest Andreas Brunsson in 1135. In Iceland and Sweden it was not recorded until the end of the $13^{\text {th }}$ century, with a few exceptions

12 The old Scandinavian names were still common in rural areas where the ecclesiastical influence was not so strong (Halvorsen 1968). 
of three runic inscriptions in the province of Västergötland in the $12^{\text {th }}$ century. The forms Andres and Anders became two of the most used Swedish male names, both in the higher and the lower ranks of society towards the late mediaeval times.

The use of the same popular given names for various individuals meant that a more specific identification was need. Therefore, bynames appeared among all the ranks of society to differentiate and characterize an individual. As in the Viking Age, bynames were formed as an attributive addendum, often an appositional element to the baptismal name.

Patronymics, i.e. names derived from a close relative, mostly one's father, occurred as true patronymics ${ }^{13}$ in mediaeval inscriptions, for instance the compound Ulfssun instead of the old form sun Ulfs (Modéer 1989: 969) or the early Danish suen sazersucen 'Saserson' (Kousgård Sørensen 1984). Melefors (2002) notes that this development can be analyzed as parallel to or depending on Latin flexional patronymics such as Ericus Olai for Erik Olafsson. On the other hand, matronymics were rarely in use, unless the mother's rank was regarded higher than the father's (Kousgård Sørensen 1984, Johannessen 2001):

\section{(11) Karl Ingeborgsen, Peder and Ubbe Bodilsen, Sven Estridsen}

During the Middle Ages, an occupational name might be added to a person's given name to describe the person's profession. Some examples from a Danish charter from the $14^{\text {th }}$ century are given below (Melefors 2002: 969):

(12) a. Magnus Muramastrare 'mason'

b. Olaff Kiøtmangare 'butcher'

c. Peter Skomakare 'shoe-maker'

Although in Icelandic sagas names containing jarl 'earl', konungr 'king' or skáld 'poet' could imply the occupation, names derived from certain professions such as Biscop 'bishop', Kesare 'emperor' or Pape 'pope' could be used ironically and humorously rather than to reflect the actual profession (Modéer 1989).

Other frequent types of bynames are epithets ${ }^{14}$ given to an individual, usually derived from a noun or an adjective. Such names would pass down through generations, even though these often had pejorative undertones (Melefors 2002: 969):

(13) Get 'goat', Gylta 'sow', Puke 'devil', Raf 'fox'

Most bynames are adjectival and can be easily recognized and interpreted (14a), while others are less transparent and their meaning can only be speculated upon (14b) (Melefors 2002: 969):

13 Taking the father's given name, still in use in Iceland.

14 Descriptive appellatives accompanying the given name. 
(14) a. Bred 'broad', Diger, Digre 'big, fat', Gammal 'old', Flatnefr 'flatnose', Kroknaf 'bent nose', Lang 'long', Peder Timberman medh ena ögat 'Peder Timberman with one eye'

b. Hjalti jarnauga 'iron eye', Olafuer Graflax 'raw spiced salmon', porsteinn blindingr 'blind man'

In other cases, the place of birth or residence could be directly inserted in front of the given name or expressed via a derived form, e.g an adjective (15a). As very few people had family names, it was common to derive the inherited name from place names, after German patterns (15b):

(15) a. Conradus and Hinricus Arxø probably from the island of Hargön, Laurencius Bobicergh, originally a place name

b. Einarr gotneski 'the Gotlander', Gnúpa-Bárðr for someone from or living in Gnúpar in Fljótshverfi

New sources that attest personal nomenclature emerged towards the end of the Middle Ages. Parchment letters, landed property registers and account books used by the Church and the nobility started to record transactions and the names of the individuals involved. As a result, the larger number of sources provides valuable insights into the origin and use of personal names in the $14^{\text {th }}$ and $15^{\text {th }}$ centuries.

Another influence on name-giving came at the end of the $13^{\text {th }}$ century, when German personal names started to appear in German-speaking towns and mining areas in the Scandinavian countries. The prescription issued by the Swedish king Magnus Eriksson in 1347 that all letters should be written in the vernacular proved to be significant as many names were written in their Nordic form and people generally associated with the Church could retain the Latin forms.

According to Wiktorsson (2005), native dithematic personal names started to decline in favor of names that the Church had to offer at baptism. As discussed above, the stock of religious personal names mostly include imported biblical and saints' names that developed with slight alternations along the centuries due to Low German and French influences:

(16) Abraham < Abraham, Anne $e^{15}<$ Anna, Anders $<$ Andreas, Daniel $<$ Daniel, David $<$ David, Isak < Isaak, Jakob < Jacob, Johan < Johannes, Karin < Katarina, Magda < Magdalena, Martin $^{16}<$ Martinus, Mikael $<$ Michael, Nils $<$ Nikolaus, Simon $<$ Simon, Tomas $<$ Thomas

Changes in the vernacular, such as the use of shortened and simplified forms of first names, made Latin and other foreign names easier to handle. Thus, the following forms were in use in Sweden (Pettersson 2014: 246):

15 The French spelling reflects the French influence during the Gustavian era in late $18^{\text {th }}$ century.

16 After Saint Martinus van Tours (316-397). After Martin Luther's Reformation the name became more common. 
(17) a. Benediktus - Benedikt - Bengt - Bent

b. Birgitta - Birgit - Britta - Berit - Berta

c. Georgius - Georg - Göran - Jörgen - Örjan

d. Johannes - Johan - Jon - Jöns - Hans

e. Laurentius - Laurenz - Lorens - Lars

f. Margareta - Margit - Greta

g. Mattias - Mattis - Mats

h. Nikolaus - Niklas - Nils - Nisse - Klas

i. Petrus - Peder - Per-Peter - Petter

As Leibring (2016) observes, the use of the name Maria was already very common during the Middle Ages in Southern Europe, but not in Northern Europe, as it was considered too sacred to be given to mortals. After the Reformation (1517), the names became popular both in Germany and Scandinavia.

Wiktorsson (2005: 1175) lists the following ten most common male and female names, in order of frequency, in Sweden during the Middle Ages:

Table 1. Male and female names in mediaeval Sweden

\begin{tabular}{|l|l|}
\hline Male names & Female names \\
\hline Johan, Jöns $<$ Johannes & Katarina, Karin \\
\hline Peter, Per $<$ Petrus & Kristina, Kerstin \\
\hline Olof, Olle (Norwegian king and saint) & Margareta, Margit \\
\hline Niklas, Nils (< Nikolaus) & Ingeborg \\
\hline Magnus & Birgitta, Britta $(<$ Birgitta, Swedish saint) \\
\hline Laurens, Lars, Lasse (< Laurentius) & Elena, Elin $(<$ Helena) \\
\hline Benedikt, Bengt & Anna (mother of Virgin Mary) \\
\hline Erik & Ingrid \\
\hline Anders (< Andreas) & Cecilia, Sissa \\
\hline Karl & Ingegärd \\
\hline
\end{tabular}

As can be seen, the majority are Church names and a few are royal names. However, as Wiktorsson (1983) notes, these are mostly upper class names that are recorded in written mediaeval sources and thus the general picture of given names is not completely accurate, especially regarding female names.

\section{Conclusions}

Diachronic studies of the development of personal names not only reveal linguistic features, language contact and lexical influence, but also help create a sociohistorical background against which a linguistic landscape can be analyzed. Therefore, a thorough examination of personal names is needed for a better understanding of the linguistic and the socio-historical context that characterizes the Nordic countries during the mediaeval period. 
The effects of Christianization and the Latin influence on the Old Nordic onomasticon are attested by the numerous instances of personal names found in runic inscriptions which show the coexistence of both native and foreign forms. However, the old dithematic system of Germanic personal names appears less frequently as religious names rise and gain popularity as a result of the transition to the new faith. Hence, the analysis of personal names based on written sources indicates a mild conflict between the old religion and the new one. Towards the end of the Middle Ages, the nomenclature system becomes more stable due to early processes in language standardization, but will face three other waves of influence, namely German, French and English, before the present century.

\section{Bibliography}

Astås, R. 2002. Language contact during the Old Nordic period III: The impact of Christianity on Old Nordic. In The Nordic Languages, vol. 1, O. Bandle, K. Braunmüller, E. H. Jahr, A. Kraker, H. P. Naumann, and U. Teleman (eds.), 1045-1052. Berlin/New York: Walter de Gruyter.

Bergman, G. 1980. Kortfattad svensk språkhistoria. Stockholm: Prisma

Birkmann, T. 1995. Von Ågedal bis Malt. Die skandinavischen Runeninschriften vom Ende des 5. bis Ende des 9. Jahrhunderts. Berlin: Walter De Gruyter.

Brylla, E. 2016. Bynames and nicknames. In The Oxford Handbook of Names and Naming, C. Hough (ed.), 382-394. Oxford: Oxford University Press.

Eldblad, A. 1994. Johan, Jöns och Hans - tre medeltida namn med gemensamt ursprung. SAS 12: 51-74.

Evert, E. 2002. The development of Old Nordic personal names. In The Nordic Languages, vol. 1, O. Bandle, K. Braunmüller, E. H. Jahr, A. Kraker, H. P. Naumann, and U. Teleman (eds.), 963-972. Berlin/New York: Walter de Gruyter.

Gillingstam, H. 1971. Slektsnavn. Sverige. In KLNM 16: 207-209.

Halvorsen, E. F. 1968. Personnavn. Island og Norge. In KLNM 13: 199-206.

Haugen, E. 1982. Scandinavian Language Structures: A Comparative Historical Survey. Tübingen: Niemeyer.

Johannessen, O.-J. 2001. "Var han kendr við moður sína”. Metronymika, metronymikonbruk og metronymikonbærere i norrøn middelalder. SAS 19: 31-83.

Kent, N. 2008. A Concise History of Sweden. Cambridge: Cambridge University Press.

Kousgård Sørensen, J. 1984. Patronymer i Danmark 1. Runetid og middelalder. Navnestudier udg. af Institut for Navneforskning 23: 394-403.

Kousgård Sørensen, J. 1990. The change of religion and the names. In Old Norse and Finnish Religions and Cultic Place-Names. Based on Papers Read at the Symposium on Encounters between Religions in Old Nordic Times and on Cultic Place-Names, T. Ahlbäck (ed.), 394-403. Åbo/Stockholm: The Donner Institute.

Larsen, K. 1948. A History of Norway. Princeton: Princeton University Press.

Leibring, K. 2016. Given names in European naming systems. In The Oxford Handbook of Names and Naming, C. Hough (ed.), 199-213. Oxford: Oxford University Press.

Melefors, E. 2002. The development of Old Nordic personal names. In The Nordic Languages, 
vol. 1, O. Bandle, K. Braunmüller, E. H. Jahr, A. Kraker, H. P. Naumann, and U. Teleman (eds.), 963-971. Berlin/New York: Walter de Gruyter.

Modéer, I. 1989. Svenska personnamn: Handbok för universitetsbruk och självstudier. Lund: Studentlitteratur.

Peterson, L. 1988. Mono- and dithematic personal names in Old Germanic. In Probleme der Namenbildung: Rekonstruktion von Eigennamen und der ihnen zugrundeliegenden Appellative: Akten eines internationalen Symposiums in Uppsala, T. Andersson (ed.), 121-130. Uppsala: Almqvist \& Wiksell.

Peterson, L. 2002. Developments of personal names from Ancient Nordic to Old Nordic. In The Nordic Languages, vol. 1, O. Bandle, K. Braunmüller, E. H. Jahr, A. Kraker, H. P. Naumann, and U. Teleman (eds.), 745-753. Berlin/New York: Walter de Gruyter.

Pettersson, G. 2014. Svenska språket under sjuhundra år. Lund: Studentlitteratur AB.

Reichert, H. 2002. Nordic language history and religion/ecclesiastical history. I: The preChristian period. In The Nordic Languages, vol. 1, O. Bandle, K. Braunmüller, E. H. Jahr, A. Kraker, H. P. Naumann, and U. Teleman (eds.), 389-402. Berlin/New York: Walter de Gruyter.

Schottmann, H. 2002. Nordic language history and religion / ecclesiastical history II: Christianization. In The Nordic Languages, vol. 1, O. Bandle, K. Braunmüller, E. H. Jahr, A. Kraker, H. P. Naumann, and U. Teleman (eds.), 403-411. Berlin/New York: Walter de Gruyter.

Sundqvist, O. and A. Hultgård. 2004. The lycophoric names of the $6^{\text {th }}$ to $7^{\text {th }}$ century Blekinge runestones and the problem of their ideological background. In Namenwelten: Orts- und Personennamen in Historischer Sicht, A. van Nahl, L. Elmevik, and S. Brink (eds.), 583-602. Berlin/New York: Walter de Gruyter.

Wessén, E. 1927. Nordiska namnstudier. Uppsala: Almqvist \& Wiksell.

Wiktorsson, P.-A. 1983. Personnamn i det medeltida Örebro. Örebro: Örebro högskolas skriftserie. Wiktorsson, P.-A. 2005. The development of personal names in the Late Middle Ages I: The Nordic Languages. In The Nordic Languages, vol. 2, O. Bandle, K. Braunmüller, E. H. Jahr, A. Kraker, H. P. Naumann, and U. Teleman (eds.), 1171-1187. Berlin/New York: Walter de Gruyter. 